\title{
ILUSTRANDO: O LIVRO EM VITRINE E O OUE MAIS!?: O DISCURSO SOBRE O LIVRO E A CONSTRUÇÃO DE IMAGENS EM MATÉRIAS DA FOLHA DE S. PAULO ${ }^{1}$
}

\author{
Luiz Augusto ELY* \\ Lígia NEGRI**
}

- RESUMO: Este trabalho é resultado de nossa pesquisa em que investigamos os recursos quando se tem o objeto "livro" como fonte de notícia em matérias publicadas pelo jornal Folha de S. Paulo, veiculadas no mês de março de 2008 no caderno de variedades - Ilustrada - e no suplemento literário - Mais!. Assim, nos deparamos com uma diversidade de textos, compostos por gêneros discursivos característicos; entretanto, certos textos nos chamaram a atenção, pois, ainda que publicados como matérias de jornal, mais parecem textos literários, devido ao espaço em que são divulgados e, certamente, por conta do público a quem são destinados. Além disso, podemos conceber que os discursos representam o mundo e, assim, suas enunciações são parte integrante desse mundo representado, daí a associação entre essa concepção e a categoria de cena da enunciação. Desse modo, nos faremos valer dos conceitos de ethos e pathos, afinal, ainda que tenhamos dois cadernos de um mesmo jornal, estes periódicos são pensados tendo como público sujeitos distintos. E, ao considerar essas noções, pretenderemos apontar a construção de imagens de leitores na constituição das imagens dos cadernos analisados, bem como justificar essa abordagem distinta da Folha de S. Paulo ao se tomar o objeto "livro" como notícia.

- PALAVRAS-CHAVE: Cena da enunciação. Discurso. Ethos. Livros. Pathos.

\section{Introdução}

Desde a Antiguidade até os dias atuais, é consensual que o objeto "livro" sempre chamou muita atenção para si, pois quem possui um livro geralmente sabe ler e, em nossa sociedade, saber ler representa um determinado poder, poder este simbolizado pela primazia do livro como suporte da voz da razão e do saber, ou seja, como um demarcador do mundo da cultura e da erudição.

\footnotetext{
1 Este trabalho é resultado de análises realizadas em dissertação de mestrado apresentada por Luiz Augusto Ely ao Programa de Pós-Graduação em Letras, área de concentração em Estudos Linguísticos, da Universidade Federal do Paraná (UFPR), como parte das exigências para a obtenção do título de Mestre em Letras, sob orientação da Profa. Dra. Lígia Negri.

* UFPR - Universidade Federal do Paraná. Curitiba - PR - Brasil. 80.060-150 - luizaugustoely@gmail.com

** UFPR - Universidade Federal do Paraná. Departamento de Linguística, Letras Clássicas e Vernáculas. Curitiba - PR - Brasil. 80.060-150 - lignegri@ufpr.br
} 
Assim, poderíamos refletir tendo em vista o sistema dos livros como a expressão de uma vontade de verdade, definida nas palavras de Michel Foucault (2004, p.17) como sendo, possivelmente, o "[...] modo como o saber é aplicado em uma sociedade, como é valorizado, distribuído, repartido e de certo modo atribuído."

Desse modo, podemos inferir a constituição de uma possível ordenação do discurso a partir da ordem apresentada pelos livros, uma vez que esta supõe toda uma cadeia em que estariam envolvidos elementos acerca da produção, da distribuição, da comunicação e, sobretudo, da recepção e do acesso ao mundo dos livros, sendo relevante, portanto, uma análise não só dos mecanismos que tocam a leitura, mas também um estudo a propósito do universo que a envolve e faz com que se desenvolva em suas diversas formas. ${ }^{2}$

Assim, é possível observar que a mídia de uma forma geral aponta como leitura exclusivamente a leitura de livros de literatura, sendo um bom leitor, portanto, o indivíduo que se aproprie dos textos dos grandes autores, das obras de referência, ou seja, dos cânones literários.

Tendo em vista esse cenário e estabelecendo uma relação por meio de uma abordagem de como a mídia pensa e vislumbra o livro, é possível afirmar que lhe é dado um tratamento "especial", seja no jornal, seja na revista, pois na grande maioria dos enunciados em que o "livro" é referenciado, lhe é atribuído um caráter de entidade, de objeto sagrado.

A pesquisadora Isabel Travancas, em O Livro no jornal (2001), nos mostra as ligações entre esses objetos tão distintos e ao mesmo tempo tão próximos: o livro e o jornal. A autora aponta uma reflexão sobre a forma como o jornal se refere ao livro, ou seja, como um produto de uma sociedade de massa, um centro de notícia. Para realizar tal reflexão, faz uma comparação entre quatro suplementos literários - Idéias (Jornal do Brasil), Mais! (Folha de S. Paulo), Les Livres (Libération) e Le Monde des Livres (Le Monde) - do Brasil e da França, países formados por sociedades modernas, capitalistas, com uma indústria cultural dinâmica e em que o livro possui grande valor simbólico. A autora afirma que

[...] os cadernos de livros dos quatro jornais podem ser vistos como uma categoria de apreensão da realidade. Como tal valorizam alguns aspectos do vasto universo dos livros, dos quais são incentivadores e defensores. Um dos primeiros dados percebidos ao longo dessa análise é o lugar de destaque da literatura em geral e, nela, o romance é o gênero predileto. (TRAVANCAS, 2001, p.61).

\footnotetext{
O historiador Roger Chartier apresenta, de forma mais detalhada, aspectos a respeito desse fenômeno em obras como, por exemplo, A aventura dos livros: do leitor ao navegador. São Paulo: Editora da Universidade Estadual Paulista: Imprensa Oficial do Estado, 1999; e A ordem dos livros: leitores, autores e bibliotecas na Europa entre os séculos XIV e XVIII. Brasília: Editora da Universidade de Brasília, 1994.
} 
[...] Assim, os suplementos se tornam, por um lado, o lugar privilegiado de expressão do livro, - atingindo um público específico e segmentado, um público considerado leitor em potencial dos livros ou 'já leitor' -, e por outro o instrumento de transmissão de uma noção particular da literatura e do livro de um modo geral. (TRAVANCAS, 2001, p.27).

Ela também observa que

[...] ainda que pareça óbvio, o fato de o jornal defender o livro, lutar pela sua existência e incentivar a leitura como ponto fundamental de crescimento de um país, é por estar próximo a ele, já que ambos são fruto da escrita, importante aquisição humana. [...] O livro é um objeto a ser 'protegido' e incentivado. (TRAVANCAS, 2001, p.66).

Motivados por esse breve panorama, passamos a observar os textos veiculados pelo jornal impresso de maior circulação no Brasil, a Folha de S. Paulo, por meio de matérias acerca de toda e qualquer referência aos livros, publicadas principalmente em seu caderno de variedades, Ilustrada, e em seu suplemento literário, à época intitulado Mais!. Assim, pretendemos apresentar uma reflexão a partir da problemática proposta e debatida nos domínios dos estudos da Análise do Discurso de linha francesa (AD), tomando como referência textos publicados pelo jornal em que o objeto "livro" é fonte de notícia. Os textos considerados aqui para análise foram veiculados no mês de março de 2008.

Para realizar a análise vamos utilizar como referencial teórico conceitos debatidos por Dominique Maingueneau, a saber, aqueles relacionados às cenas de enunciação. Procuraremos configurar nossos procedimentos de análise no intuito de perceber a construção de imagens de leitores tomando como base o discurso sobre o livro em matérias da Folha e projetando uma imagem de "leitor ideal" para cada tipo de caderno, supondo-se, neste momento ainda a priori, que o leitor do caderno Ilustrada e o do suplemento Mais! sejam, possivelmente, distintos. Essa percepção nos conduz a pensar tal distinção a partir dos conceitos de ethos e pathos, representados, respectivamente, como a imagem do enunciador e a imagem do enunciatário, ambas determinadas pelo discurso.

\section{Princípios e procedimentos de uma análise discursiva: as cenas de enunciação e a construção de imagens pelo discurso - o ethos e o pathos}

Considerando o breve cenário acima, passemos então aos princípios e procedimentos que nos ajudarão a refletir acerca de questões que envolvem os nossos dados. Nosso referencial teórico está definido a partir de categorias de análise elaboradas por Dominique Maingueneau. Segundo o autor, é por meio das formas literárias que se manifesta o pensamento que a literatura produz, lembrando 
que a literatura não condiciona apenas um discurso sobre o mundo, mas produz, inclusive, sua própria presença nesse mundo, no sentido em que

[...] a obra, por meio do mundo que configura em seu texto, reflete, legitimando-as, as condições de sua própria atividade enunciativa. Vem daí o papel crucial que deve desempenhar a 'cena de enunciação' que não é redutível nem ao texto nem a uma situação de comunicação do exterior que se possa descrever. A instituição discursiva é o movimento pelo qual passam de uma para a outra, a fim de se alicerçar mutuamente, a obra e suas condições de enunciação. Esse alicerçar recíproco constitui o motor da atividade literária. (MAINGUENEAU, 2006b, p.54).

Em outras palavras, o autor aponta ainda que

[...] 'vulgarizam-se', por exemplo, os enunciados científicos, e não os enunciados literários. Para o comentário desses últimos existe um conflito permanente entre duas instâncias de legitimação: os sábios, legitimados pela Escola, e os amadores, que reivindicam para si uma relação privilegiada, pessoal com os textos. (MAINGUENEAU, 2006a, p.46).

Para caracterizar essa diversidade dos discursos, Maingueneau lança mão de três concepções de cenas de enunciação: a cena englobante, a cena genérica e a cenografia.

A cena englobante corresponde ao tipo de discurso, entendido como cenário mais amplo, em que teríamos os discursos: religioso, político, publicitário, científico, literário, etc. É essa cena que permite nos situarmos para interpretar um texto, e é também responsável por definir a situação dos parceiros e de um determinado quadro espaço-temporal.

Já a cena genérica está relacionada ao gênero de discurso, em que cada gênero define seus próprios papéis. Conforme exemplos mostrados pelo autor, em um panfleto de campanha eleitoral, o papel definido, quase que impositivamente, é de um candidato dirigindo-se a eleitores; ou em uma sala de aula, trata-se de um professor dirigindo-se a alunos.

Essas duas cenas, segundo o autor, irão nos conduzir à cenografia, responsável por definir o espaço no interior do qual o enunciado adquire sentido, espaço esse determinado pelo tipo e pelo gênero de discurso. Nesse sentido, a cenografia é uma constituição discursiva e não extradiscursiva:

Todo discurso, por sua manifestação mesma, pretende convencer instituindo a cena de enunciação que o legitima. [...] Com efeito, tomar a palavra significa, em graus variados, assumir um risco; a cenografia não é simplesmente um quadro, um cenário, como se o discurso aparecesse 
inesperadamente no interior de um espaço já construído e independente dele: é a enunciação que, ao se desenvolver, esforça-se para construir progressivamente o seu próprio dispositivo de fala. [...] Desse modo, a cenografia é ao mesmo tempo a fonte do discurso e aquilo que ele engendra; ela legitima um enunciado que, por sua vez, deve legitimá-la, estabelecendo que essa cenografia onde nasce a fala é precisamente a cenografia exigida para enunciar como convém, segundo o caso, a política, a filosofia, a ciência. (MAINGUENEAU, 2005, p.87-88).

Ainda, para Maingueneau (2005, p.229), é a cena enunciativa, “[...] com efeito, que desempenha o papel de pivô entre a organização lingüística do texto e o discurso como instituição de fala e instauração de um evento verbal no mundo." Afinal, para o autor, "[...] um texto não é um conjunto de signos inertes, mas o rastro deixado por um discurso em que a fala é encenada." (MAINGUENEAU, 2005, p.85).

A caracterização dos discursos a partir da sua configuração em diferentes cenas de enunciação, tal como proposta por Maingueneau, mostra-se bastante apropriada para o tratamento dos dados que pretendemos focalizar. Além disso, recorremos ainda a outras duas noções que nos ajudarão a empreender a análise desejada, a saber: as categorias de ethos e pathos discursivo.

Ainda que a noção em torno do conceito de ethos seja, comumente, aquela proposta pela retórica aristotélica, revitalizada pela moderna retórica argumentativa, atualmente temos observado um novo domínio de configuração deste termo dentro do campo da Análise do Discurso. O ethos, para a Retórica, se configura como um meio de persuasão, diferentemente do que se pode constatar em Análise do Discurso, em que ele é concebido como parte constitutiva da cena de enunciação, uma instauração progressiva de seu próprio dispositivo de fala, entendido como quadro e processo.

Desse modo, ainda segundo Maingueneau, a cenografia não pode se configurar plenamente se não puder controlar seu próprio desenvolvimento, assim como o ethos que dela participa, mantendo uma distância em relação a um co-enunciador, que não pode agir imediatamente sobre o discurso, em que a fala, desde a sua emergência, supõe uma certa cena de enunciação que, de fato, se valida progressivamente por essa mesma enunciação. São os conteúdos desenvolvidos pelo discurso que permitem especificar e validar a própria cena e o próprio ethos, pelos quais esses conteúdos surgem.

Corroborando as reflexões desenvolvidas por Maingueneau, Fiorin (2008, p.139) também discute e opera com a noção de ethos e afirma que

[...] por conseguinte, o éthos explicita-se na enunciação enunciada, ou seja, nas marcas da enunciação deixadas no enunciado. [...] Trata-se de apreender um sujeito construído pelo discurso e não uma subjetividade que seria a fonte de onde emanaria o enunciado, de um psiquismo 
responsável pelo discurso. O éthos é uma imagem do autor, não é o autor real; é um autor discursivo, um autor implícito.

Nesse sentido, podemos, além do ethos, apreender também a imagem do enunciatário, o pathos, afinal aquele que fala constrói aquele que ouve e é, ao mesmo tempo, construído por ele; assim, o ethos e o pathos nos são dados no texto e pelo texto, conforme podemos verificar em Fiorin (2008, p.157):

\begin{abstract}
Por outro lado, o enunciatário adere ao discurso, porque nele se vê constituído como sujeito, identificando-se com um dado éthos do enunciador. A eficácia do discurso ocorre, quando o enunciatário incorpora o éthos do enunciador. Essa incorporação pode ser harmônica, quando éthos e páthos ajustam-se perfeitamente [...] ou complementar, quando o éthos responde a uma carência do páthos. [...] A eficácia discursiva está diretamente ligada à questão da adesão do enunciatário ao discurso. O enunciatário não adere ao discurso apenas porque ele é apresentado como um conjunto de idéias que expressa seus possíveis interesses, mas sim, porque se identifica com um dado sujeito da enunciação, com um caráter, com um corpo, com um tom. Assim, o discurso não é apenas um conteúdo, mas também um modo de dizer, que constrói os sujeitos da enunciação. O discurso, ao construir um enunciador, constrói também seu correlato, o enunciatário.
\end{abstract}

Tendo em vista as noções de cenas da enunciação e as de ethos e pathos discursivo, em desenvolvimento nos domínios da Análise do Discurso de linha francesa, propusemo-nos a confrontar as matérias que tematizam o "livro" nos cadernos selecionados da Folha de S. Paulo.

\title{
Ilustrando: o livro em Vitrine e o que Mais!?
}

Em sua circulação habitual, a Folha de S. Paulo, no período em que foram publicados os textos que aqui analisaremos - março de 2008 -, contava com uma diversidade de cadernos: o primeiro, que versava sobre questões relacionadas à opinião do jornal, bem como aquelas relacionadas ao "mundo do poder", com notícias nacionais e internacionais; um segundo, que focalizava assuntos econômicos; um terceiro caderno, em que eram abordadas notícias do "cotidiano", além de temas de divulgação científica e de saúde; um caderno sobre esportes; o caderno de variedades, denominado Ilustrada, basicamente constituído por textos de entretenimento, sobre cinema, música, teatro, televisão, e também com notícias do mundo das celebridades; e um último, que poderia ser definido como um suplemento literário. À época da realização de nossa coleta de dados, este caderno tinha como título Mais!; entretanto, por conta de uma reformulação gráfica e editorial do jornal, ocorrida em meados do ano de 2010, este caderno passou a se chamar Ilustríssima, e, de uma certa forma, ficou mais "forte" que 
antes, pois é possível perceber que são tratados, de maneiras diversas, assuntos relacionados a aspectos da cultura em geral, e não apenas de temas relacionados ao mundo dos livros, sendo sua circulação apenas aos domingos, também como acontecia em 2008.

Considerando a constituição do jornal desse momento, podemos observar que, usualmente, a Folha publicava notas, resenhas, matérias comentando o lançamento de livros, enfim, uma gama de textos de gêneros variados que forma o todo do jornal. No caderno de variedades da Folha, a Ilustrada, essa multiplicidade de matérias é maior, já que sua circulação é diária e seu público leitor é bastante heterogêneo. Porém, as edições de sábado desse caderno dão uma atenção especial aos livros, pois nelas são publicadas resenhas e uma série de outros textos em que o objeto "livro" é o assunto principal.

Diferentemente da Ilustrada, o caderno Mais!, conforme já mencionamos, no ano de 2008 circulava apenas aos domingos; tratava não só de livros, mas de assuntos mais "densos", afinal muitos dos autores desses textos são intelectuais e professores universitários renomados. Podemos observar uma linguagem mais "apurada", mais rebuscada, seja na sintaxe seja na seleção lexical. Nesse sentido, apontaremos como exemplo um texto publicado no domingo, dia 02 de março de 2008, na seção "Biblioteca Básica" desse suplemento.

Para cada época da vida, tive um livro mais importante: A Bíblia, 'Crime e Castigo' (Dostoiévski), 'O Ateneu' (Raul Pompéia), 'Clara dos Anjos' (Lima Barreto), 'Introdução à Revolução Brasileira' (Werneck Sodré). Meu livro de longa duração é 'Memórias do Cárcere' [ed. Record], de Graciliano Ramos. Não é ficção, não é memória, não é depoimento político, é tudo isso.

O conteúdo (a brutalidade da cadeia) só se revela por meio daquela forma. 'Memórias do Cárcere' é a chave dos romances de Graciliano. A chave está fora, embora também seja texto. Um fora dentro. (SANTOS, 2008).

O texto publicado pelo jornal foi reproduzido integralmente, para demonstrar como as matérias desse tipo de seção apresentam a apreciação de um intelectual ou pessoa de destaque sobre livros que deveriam compor a nossa "biblioteca básica".

Retomamos aqui a observação feita pelo jornal: Joel Rufino dos Santos (2008) (autor do texto publicado pelo Mais!) é professor da Universidade Federal do Rio de Janeiro (UFRJ) e elabora um breve comentário a respeito do livro Memórias do Cárcere, de Graciliano Ramos (anexo 01). ${ }^{3}$ É interessante observar que o professorautor cita o título de outras obras - a Bíblia; Crime e Castigo, de Dostoiévski; O

Os textos integrais das matérias da Folha de S. Paulo que aqui comentamos estão dispostos ao final do trabalho, sob a forma de anexo. 
Ateneu, de Raul Pompéia; Clara dos Anjos, de Lima Barreto; e ainda, Introdução à Revolução Brasileira, de Werneck Sodré - e as retoma ao apresentar a obra que vai comentar. Desse modo, ao considerarmos o texto publicado pelo jornal, é possível constatar que, mesmo em uma pequena extensão, e por meio de uma linguagem um pouco mais elaborada como o recurso a oxímoros e antíteses, por exemplo - "não é ficção, não é memória, não é depoimento político, é tudo isso" ou "um fora dentro" - pode-se tecer um comentário não tão simples, tendo em vista o suporte em que se veicula um texto e quem se espera que vá ler esse texto.

Em um outro exemplo (anexo 02), também publicado nessa seção, no dia 09 de março de 2008, o diretor da companhia teatral "Os Satyros", Rodolfo García Vázquez (2008), tece uma análise sucinta do livro Ética contra estética, da autora espanhola Amelia Valcárcel. Segundo García Vázquez, em seu livro a autora aborda, a partir de uma relação entre o "bem" e o "belo", aspectos "[...] das visões dos pensadores clássicos e sem dar uma resposta definitiva a esse combate de valores supremos.", que, na opinião do diretor teatral, em um país como o Brasil, uma reflexão como essa seria essencial àqueles envolvidos com o mundo das artes e da cultura de um modo geral.

Assim, por meio das palavras de Isabel Travancas e tendo em vista esses exemplos retirados do caderno Mais!, podemos considerar o suplemento literário como

[...] não sendo mais um espaço de crítica literária, mas um lugar predominantemente jornalístico com contribuições mais ou menos freqüentes dos acadêmicos. Como tal estão mergulhados em uma lógica jornalística que define os cadernos a partir do conceito de notícia. (TRAVANCAS, 2001, p.16).

Por outro lado, notamos que em quase todos os textos publicados na Ilustrada há, ao final da resenha, um pequeno quadro descritivo em que são apresentadas informações acerca dos livros "noticiados": título, autor, tradutor (caso seja uma obra de literatura estrangeira), editora, valor (referência ao preço), número de páginas e, uma informação extra para o leitor, uma avaliação a propósito do livro, avaliação essa que pode variar, apontando o livro como ótimo, bom ou regular.

Na sua edição do sábado, dia 08 de março de 2008, a Ilustrada publicou um texto de autoria de Noemi Jaffe (2008) (anexo 03), que, em "colaboração para a Folha", apresenta a coletânea de Histórias para ler sem pressa, tradução de Mamede Mustafá Jarouche de trinta narrativas curtas produzidas entre os séculos 8 e 18, em que se pretende retratar, por meio da irreverência, a sabedoria árabe. São textos retirados de fontes como "O Livro das Grandes Categorias" ou "O Livro dos Inteligentes", em que a sabedoria, assim como a inteligência, é vista como virtude, desenvolvendo-se a partir da experiência, e exigindo, portanto, tempo para se consolidar. Nas Histórias, diz a articulista, os sujeitos 
são representados pelos tipos já conhecidos: o avarento, o ridículo, ou o esperto que não se dá bem no final; assim como também estão presentes os justos, os generosos... Jaffe afirma, ainda, que as passagens são relatadas de forma simples, porém, sem permitir que o leitor seja encaminhado ao senso comum a respeito da boa moral e dos bons costumes.

Como já mencionamos, ao final do texto nos deparamos com informações a respeito da obra resenhada: título; organização e tradução (nesse caso, por se tratar de uma coletânea de textos estrangeiros organizados e traduzidos por Mamede Mustafá Jarouche); a editora que está publicando o livro; qual será o preço do livro quando estiver à venda; número total de páginas; além de um conceito (avaliação) do jornal sobre a obra que, nesse caso, foi considerada ótima.

Vejamos ainda um outro texto desse mesmo fascículo. Também em 08 de março de 2008, foi publicada uma matéria que noticiava a reedição de duas obras de João Ubaldo Ribeiro: Sargento Getúlio e Viva o povo brasileiro (anexo 04). Além de anunciar o relançamento de títulos do autor baiano pela editora Alfaguara/ Objetiva, o colunista Manuel da Costa Pinto (2008) apresenta ao leitor o enredo dos livros, bem como características do estilo de Ubaldo Ribeiro. Ao final da resenha, as obras Sargento Getúlio e Viva o povo brasileiro são, respectivamente, classificadas como ótima e boa.

Abordando aspectos semelhantes, o caderno Mais! também publicava resenhas seguindo esse formato, entretanto não apresentava informações tão explícitas no sentido de conduzir (ou não) o leitor do jornal à leitura do livro que está sendo resenhado. Quando da análise acerca do caderno Mais!, comentaremos esse tipo de resenha a fim de explicitarmos parâmetros possíveis de comparação.

Na edição de domingo, 09 de março de 2008, o caderno Mais! veiculou um texto da jornalista Sylvia Colombo (2008) a respeito do lançamento, no Brasil, do livro Cartas à mãe, em que estava sendo trazido a público o depoimento da franco-colombiana Ingrid Betancourt, à época, mantida refém pelas FARCs já há seis anos (anexo 05). O livro tinha como texto principal a reprodução integral da carta que Betancourt destinou à sua mãe, Yolanda, e aos filhos, Mélanie e Lorenzo. A edição brasileira trazia ainda um prefácio do Nobel da Paz, Elie Wiesel, e um posfácio de Francisco Carlos Teixeira da Silva, professor da Universidade de Brasília (UnB), além de um texto resposta dos filhos da "prisioneira". Diferentemente dos textos da Ilustrada comentados acima, as informações a respeito do livro não estão dispostas ao final da resenha, como uma espécie de quadro, mas sim ao longo do corpo do texto de Sylvia Colombo, bem como não há menção de qualquer tipo de avaliação da Folha considerando o livro resenhado ótimo, bom ou regular, como costuma ser a prática do caderno de variedades Ilustrada ao final de suas resenhas. 
Um outro exemplo como esse é o texto de Eduardo Rodrigues da Cruz (2008), publicado na edição de 16 de março de 2008 do Mais! (anexo 06). Em "especial para a Folha", o professor do Departamento de Teologia e do Programa de PósGraduação em Ciências da Religião da PUC de São Paulo apresenta considerações a propósito da sua leitura do livro O espírito do ateísmo, de autoria do filósofo André Comte-Sponville, que estava sendo lançado. Rodrigues da Cruz elabora um texto repleto de referências a outros filósofos e pensadores no sentido de dialogar com o tema da obra a ser resenhada, terminando seu texto com a recomendação da leitura do livro de Comte-Sponville e se desculpando por não ter tido a oportunidade de comparar a tradução com o original em francês: "É um livro que vale a pena ser lido, não só por apresentar o pensamento de um influente filósofo contemporâneo como por seu estilo agradável, acessível e eminentemente pessoal. Não pude compará-lo com o original francês, mas a tradução não parece apresentar problemas."

Tendo em vista esses dois textos focalizados, é possível observar que, diferentemente do que acontece com a Ilustrada, nas indicações do Mais! geralmente não há um indício de apreciação do jornal sobre o livro em questão: ou seja, podemos inferir que, diante dos textos veiculados pelo suplemento, o leitor possuiria uma certa autonomia para saber se a sugestão lhe será proveitosa ou não, sem que seja necessária a explicitação da apreciação do jornal a respeito. O que avalizaria a recomendação da leitura, portanto, é o articulista e não uma menção didática específica do jornal.

Considerando ainda outros aspectos, lembramos que a primeira seção do suplemento literário Mais! era "Os Dez +" que, segundo a definição do próprio jornal, se caracterizava como "uma seleção de livros e eventos culturais indicados pelo caderno". Nesse caso as indicações a respeito dos livros trazem sempre uma breve descrição da obra, além de informações como preço, editora, número de páginas, etc.

Na edição de domingo, dia 09 de março de 2008, por exemplo, essa seção anunciava a chegada de mais sete títulos ao mercado (OS DEZ ..., 2008a) (anexo 07): um "combo" com dois livros de João Ubaldo Ribeiro, Sargento Getúlio e Viva o povo brasileiro-obras essas que já haviam sido também noticiadas pela Ilustrada; e, ainda, Kafka à beira-mar, de Haruki Murakami; Isto é biologia, de Ernst Mayr; uma reedição do livro Abdias, segundo romance de Cyro dos Anjos; Para ler como um escritor, de Francine Prose; a coletânea de contos A fêmea da espécie, de Joyce Carol Oates, e Putas assassinas, de Roberto Bolaño.

Uma semana depois, no dia 16 de março de 2008, essa mesma seção trazia como sugestão outros sete títulos (OS DEZ..., 2008b) (anexo 08): A República, um ensaio do professor de filosofia da Universidade de Cambridge, Simon Blackburn, sobre a obra de Platão; O povo de Luzia - Em busca dos primeiros americanos, 
relato de Walter Neves e Luís Pilo sobre suas pesquisas em paleontologia; O mito individual do neurótico, reunião de três textos do psicanalista Jacques Lacan; A mulher que fugiu de Sodoma, reedição do romance de José Geraldo Vieira; também uma outra reedição, do livro Ascensão e queda do Terceiro Reich, de William L. Shirer; Nothing to be frightened of, de Julian Barnes, e Vestígio, de Patricia Cornwell.

Já na Ilustrada há uma seção que tem como título "Vitrine", em que são expostos os "produtos da semana", seguindo basicamente os mesmos princípios que a seção "Os Dez +" do caderno Mais!. Os livros são divididos entre ficção e não ficção; são apresentadas informações básicas como a editora e os seus preços. Porém, a "Vitrine" também traz uma breve biografia sobre o autor, uma pequena resenha sobre o tema abordado pelo livro e ainda, e principalmente, explicita a razão pela qual deveríamos ler os livros em destaque, como uma justificativa da indicação dos títulos pelo caderno.

Na sua edição do dia 08 de março de 2008, temos como destaque os seguintes livros (VITRINE, 2008a) (anexo 09): A cidade inteira dorme, do escritor norteamericano Ray Bradbury; La bodega, do consagrado escritor Noah Gordon; Creta, de Antony Beevor; e Por que as zebras não têm úlceras?, do biólogo e neurologista Robert M. Sapolsky. Na edição de sábado, dia 29 de março de 2008, por exemplo, temos informações sobre os seguintes livros (VITRINE, 2008b) (anexo 10): Partículas elementares, do escritor francês Michel Houellebecq; Toda poesia de Machado de Assis, de Machado de Assis; Descobertas perdidas, do autor norte-americano Dick Teresi; e Japoneses - A história do Sol Nascente, de Marcia Yumi Takeuchi.

Por sua vez, o caderno Mais!, paralelamente à seção "Os Dez +", publicava uma outra coluna, a dos "+ Lançamentos". Nesta, porém, não havia indicação de eventos culturais, mas apenas sugestões de livros, em que se divulgavam os lançamentos daquela semana, basicamente utilizando-se das mesmas informações da outra seção, conforme podemos constatar por meio dos exemplos publicados em 02 e 30 de março de 2008, apresentados nos anexos 11 e 12, respectivamente.

Semanalmente, eram listados em torno de dez títulos. No sentido de ilustrar essa ocorrência, mencionaremos aqui apenas seis, sendo os três primeiros da relação publicada no dia 02 de março, e os outros três, no dia 30: Brasil - Paisagens naturais, de Marcelo Leite; Hibridismos musicais de Chico Science e Nação Zumbi, de Herom Vargas; Leitura, literatura infanto-juvenil e educação, de Célia Regina Delácio Fernandes; A memória, a história, o esquecimento, de Paul Ricoeur; Escrever sobre escrever, de Claudia Amigo Pino e Roberto Zular, e Sotaques d'aquém e d'além mar, de Manuel Carlos Chaparro. 
Desse modo, ao compararmos as matérias de cada caderno, podemos observar que há uma certa predominância de textos de divulgação de literatura nas matérias veiculadas pela Ilustrada, ou seja, os textos mais parecem anúncios, nos quais é possível perceber a prescrição do livro e da leitura. Além disso, por meio desse "discurso de divulgação do livro", podemos apreender o espetáculo que envolve esse universo, afinal, é a recomendação da Folha, projetada como voz da autoridade, que possui o conhecimento a respeito de determinada obra, que deve operar como o critério relevante para o leitor nas suas escolhas.

Essa observação pode ser comprovada também nos textos-anúncio acerca de alguns títulos disponibilizados à venda pelo próprio jornal, em uma coleção: a "Coleção Folha Grandes Escritores Brasileiros". A cada domingo, ao comprar o jornal, o leitor poderia levar consigo uma obra de destaque da literatura brasileira. Na edição da Ilustrada do dia 02 de março de 2008, esse "anúncio" tinha como foco o livro O sentimento do mundo, de Carlos Drummond de Andrade (COLEÇÃO..., 2008) (conforme anexo 13). Para tanto, é apresentado algo semelhante a um resumo do estilo do autor mineiro, além de características da obra que estava sendo anunciada, que, segundo o texto, seria o quarto livro da coleção que estaria à venda.

Em 30 de março de 2008, noticiava-se a venda do livro da semana seguinte: Triste fim de Policarpo Quaresma, de Lima Barreto (LIVRO..., 2008) (anexo 14). Assim como o exemplo anterior, esse também segue a mesma cenografia, a mesma estrutura das resenhas cujo objetivo não era outro que não o de servir de propaganda da própria Folha ao despertar o interesse de seus leitores para que pudessem se sentir motivados a adquirir a obra em destaque.

Tendo em mente o nome da coleção - "Coleção Folha Grandes Escritores Brasileiros" -, e considerando observações feitas pela pesquisadora Isabel Travancas,

[...] é como se existisse uma grande enciclopédia literária sendo construída pela elite intelectual, que indica o que deve ser selecionado e o que deve ser excluído, apontando o que deve ser lido e permanecer para a posteridade. Muitas vezes os meios de comunicação reforçam estas escolhas, apresentando e reapresentando estas obras para o consumidor, estimulando-o a gostar do já conhecido e do já visto. (TRAVANCAS, 2001, p.85).

Ainda no que concerne à comparação entre os dois suplementos aqui focalizados, um outro aspecto a se observar diz respeito à autoria dos textos veiculados. Muitas vezes, na Ilustrada não há referência ao autor da matéria, que quase sempre vem apresentada como "da reportagem local"; enquanto que, 
no suplemento literário - Mais! -, além de as matérias serem frequentemente assinadas e o autor ter o seu nome revelado, elas exibem sempre a menção "em colaboração para a Folha", "em especial para a Folha", e raros são os textos apresentados como "da redação".

Dessa forma, tendo em vista alguns dos textos publicados pelo jornal, em que procuramos exemplificar a materialidade do discurso acerca da temática que envolve os livros e que a Folha faz circular, retomando o conceito de cena de enunciação proposto por Maingueneau, mais do que classificar as matérias como cenas englobantes ou cenas genéricas conforme a conceituação proposta pelo autor, acreditamos que possa ser pertinente, ou ainda producente, considerar os textos veiculados pela Folha tendo em mente o conceito de cenografia, uma vez que esta cena não é imposta apenas pelo tipo ou pelo gênero de discurso, mas sim instituída pelo próprio discurso.

\section{Considerações finais}

Considerando os exemplos que apresentamos anteriormente, é possível apreender cenografias distintas, dados os assuntos abordados e, principalmente, o caderno em que cada um desses textos é veiculado. A coluna "Vitrine" da Ilustrada, por exemplo, se constitui de maneira diferente da coluna "Os Dez +" ou daquela dos "+ Lançamentos", publicadas pelo suplemento Mais!. Ainda que tenhamos basicamente as mesmas informações em todas elas, o que as torna diferentes é justamente o caráter de recomendação, de prescrição do livro e da leitura, com construções do tipo "por que ler", presentes nas indicações do caderno de variedades, ou ainda com a divisão entre categorias como "ficção", "não ficção" ou "romance", bem como por meio de informações de quem foi o autor, contextualização do tema abordado pela obra, etc., configurando, desse modo, uma cenografia "professoral", pedagógica.

Outra configuração cenográfica é a dos textos-anúncio, a propósito da venda de títulos consagrados da literatura brasileira pelo próprio jornal. Esses textos são, na verdade, publicidade, uma vez que a intenção da Folha não é, ou não seria, promover determinado autor ou determinada obra, mas sim, basicamente, convencer o leitor de que o livro que será disponibilizado naquela semana é interessante e, portanto, deveria ser adquirido, já que se trata de um texto de um "grande escritor" nacional. Contudo, a cenografia é a que mimetiza a resenha literária.

A principal cenografia configurada pelas matérias do Mais! é a do ensaio acadêmico ou da resenha crítica, que se constituem como um discurso elaborado e dirigido a um interlocutor culto, capaz de assimilar e avaliar o seu teor. Assim constituído, esse tipo de discurso, de cenografia, projeta um ethos competente, 
acadêmico: que atesta domínio, "expertise" sobre o assunto. Esse ethos discursivo é constituído tanto a partir das imagens projetadas pelas matérias assinadas, quanto pela imagem do suplemento como um todo, bem como pela imagem de seu co-enunciador, o leitor projetado e considerado por esse discurso, o pathos do enunciatário: um leitor culto, ou interessado em cultura, com discernimento e capacidade de arbítrio.

Já a cenografia apreendida pelos textos do caderno Ilustrada é aquela que remete a uma resenha jornalística, com cunho puramente informativo, em que são abordados aspectos que auxiliarão o leitor nas suas escolhas, ou ainda, que podem conduzi-lo na tomada de decisões, de forma a elaborar assim seu ponto de vista. Os textos têm um forte caráter de aconselhamento ou de recomendação de leituras e de assuntos que deveriam ser do interesse do co-enunciador; nesse sentido adquirem um teor didático, que contribui para configurar uma cenografia "professoral" nesse caderno.

Esses textos muito se assemelham àqueles presentes em uma revista semanal de variedades, com temas do mundo da cultura e do entretenimento, projetando a imagem tanto de um enunciador como de um enunciatário como o "descolado", semelhante à própria imagem projetada pelo jornal: seus interesses são variados; seu envolvimento com as manifestações culturais são diversas, interessando-se, inclusive, por aquelas tidas como alternativas.

Ainda que essa seja a imagem projetada do jornal e esteja subjacente aos discursos presentes nas matérias de ambos os cadernos focalizados, a imagem que se apreende de cada um deles é perceptivelmente diferente, como se pôde verificar pelas cenografias postas em jogo em cada um: uma tutelar, outra acadêmica. Também o ethos projetado aí será diferente e contribuirá para consolidar a distinção ora apontada.

Observando-se então as diferenças demarcadas, seja em relação às cenografias preferenciais em cada caderno, seja em relação à constituição e assunção do ethos e do pathos dos co-enunciadores, acreditamos fortemente que a diferença não só em relação à linguagem utilizada na composição dos textos, mas também na constituição dos discursos sobre livros veiculados pelo jornal, deve-se, certamente, ao público a que se destinam esses textos. Infere-se, então, a partir da imagem de leitor projetada pelo ethos discursivo do enunciador da Ilustrada, um enunciatário que, muitas vezes, se constitui a partir e por meio da visão proposta pelo jornal, este um ethos projetado de autoridade máxima, de alguém dono de um saber douto sobre a questão, isto é, sobre a recomendação de livros e leituras. Ao contrário, o leitor do Mais! é assumido como um leitor com formação prévia e que, ao se deparar com as indicações do caderno, se questiona sobre o seu interesse e serventia. 
A análise demonstra que há, basicamente, duas imagens de leitores consideradas pelos textos da Folha S. Paulo para a constituição e projeção do ethos das matérias em que aborda o objeto "livro". O ethos estabelecido pela Ilustrada seria o de um enunciador generoso, solidário com o seu público, uma vez que, além de apresentar inúmeras informações acerca do mundo dos livros, recomenda aos leitores o que ler; esse ethos, segundo a caracterização clássica da retórica, se configuraria como eúnoia, que se constitui por meio da benevolência, permitindo ao seu enunciatário uma imagem agradável de si, afinal o orador nutre simpatia pelo seu auditório. Já a imagem que apreendemos a partir dos textos do Mais! é aquela em que vale a prudência, o bom senso, a ponderação, pois os textos nos permitem visualizar um enunciador competente, sensato, que não precisa exprimir maiores informações, uma vez que seu interlocutor compartilha de um mundo próximo ao seu, ou seja, é também este um intelectual, um erudito ou mesmo um principiante nessas artes, um amador das letras; nesses casos a relação que se estabelece é mais simétrica: temos então um ethos baseado na phrónesis, podendo ser classificado como ponderado. Ainda, conforme caracterização proposta por Fiorin (2008), poderíamos, inclusive, supor uma incorporação harmônica, quando ethos e pathos ajustam-se perfeitamente, que seria a condição apresentada pelo Mais!; ou complementar, que seria aquela vislumbrada pela Ilustrada, em que o ethos responderia a uma carência do pathos.

Nesse sentido, podemos pensar que, ao tomar como base os discursos sobre o livro veiculados pela Folha de S. Paulo, tendo como cenário as matérias publicadas na Ilustrada e no Mais!, teríamos a configuração de, pelo menos, dois pathos, sendo o primeiro aquele leitor atribuído pela Ilustrada, que necessita das indicações do caderno e que, em certa medida, é persuadido pela opinião do jornal. Já o segundo seria aquele construído pelas imagens dos textos do Mais!, um leitor relativamente mais autônomo, tido, na verdade, como mais um de um grupo de pares, afinal, é possível notar a seguinte característica: os textos que encontramos no suplemento literário supõem que muitos dos temas que são abordados, debatidos, já são de conhecimento do público, sendo desnecessárias, portanto, informações de ordem mais básica, genérica.

Por fim, podemos apontar que o objeto "livro" se constitui como "unidade de valor" nos cadernos de cultura da Folha de S. Paulo, seja o caderno de variedades, Ilustrada, seja o suplemento literário, Mais!. De qualquer maneira, esse assunto "valorizado", sério, não é tratado do mesmo modo pelos dois cadernos, assim como também não o é pelo ethos do próprio jornal. Dessa forma, então, tal distinção só pode ser atribuída ao endereçamento que a matéria tem, mesmo que consideremos a configuração de diferentes cenografias, conforme as categorias analíticas desenvolvidas por Maingueneau que procuramos recuperar, e que pretendemos 
associar à composição do jornal ao caracterizar a materialidade do discurso sobre o livro, sobre a prescrição de livros e leituras em suas páginas.

Nesse sentido, a causa, o responsável por essa abordagem distinta dos temas relacionados ao mundo dos livros é o leitor, sendo possível afirmar que o que define a diferença do tratamento jornalístico, no caso em tela, é o pathos, ou ainda, a imagem do enunciatário, que é diferente para cada caderno, conforme pudemos apreender pelos textos que trouxemos a título de ilustração.

ELY, L. A.; NEGRI, L. Illustration: the book in Vitrine and what Mais!?: the discourse about the book and the construction of images on subject-matter of Folha de S. Paulo. Alfa, São Paulo, v.58, n.2, p.287-321, 2014

- ABSTRACT: In this paper, we report the results of a research in which we have investigated linguistic resources when 'book' is taken as subject-matter of news. We have considered subjects presented in Folha de S. Paulo newspaper, in March 2008, and published in either its variety section - Ilustrada, or in its literary supplement - Mais!. Thus, we faced a variety of texts, composed by characteristic discursive genres. Nevertheless, some of these texts called up our attention because, even being published as news, they were similar to literary ones, probably due to the venue in which they were published and because of the intended public reader. Besides, we could conceive that discourses represent world, therefore, their enunciations are parts of represented worlds, phenomenon which justifies the association between the conception proposed by Maingueneau and the scene enunciation category. We also used the concepts of ethos and pathos, because, despite we had two sections of the same newspaper, they were developed as having distinct publics. Taking these theoretical notions as supporting frame, we intended to stress the construction of the reader's image in the constitution of the newspaper sections, as well as to justify the distinguished approach of the subject 'book' as news source by Folha de S. Paulo newspaper.

- KEYWORDS: Enunciation scene. Discourse. Ethos. Books. Pathos.

\section{REFERÊNCIAS}

COLEÇÃO traz Drummond dos temas sociais. Folha de S. Paulo, São Paulo, 02 mar. 2008. Ilustrada.

COLOMBO, S. A morte seria um alívio. Folha de S. Paulo, São Paulo, 09 mar. 2008. +Mais!.

CRUZ. E. Fé na encruzilhada. Folha de S. Paulo, São Paulo, 16 mar. 2008. +Mais! . FIORIN, J. L. Em busca do sentido:estudos discursivos. São Paulo: Contexto, 2008. FOUCAULT, M. A ordem do discurso. Tradução de Laura Fraga de Almeida Sampaio. 11.ed. São Paulo: Loyola, 2004.

GARCÍA VAZQUEZ, R. Ética contra estética. Folha de S. Paulo, São Paulo, 09 mar. 2008. +Mais!, Biblioteca básica. 
JAFFE, N. História para ler sem pressa. Folha de S. Paulo, São Paulo, 08 mar. 2008. Ilustrada.

LIVRO de Lima Barreto é o próximo da "Coleção". Folha de S. Paulo, São Paulo, 30 mar. 2008. Ilustrada.

MAINGUENEAU, D. Cenas da enunciação. Organização de Sírio Possenti e Maria Cecília Pérez de Souza-e-Silva. Curitiba: Criar Edições, 2006a.

. Discurso literário. Tradução de Adail Sobral. São Paulo: Contexto, 2006b. Análise de textos de comunicação. Tradução de Cecília P. de Souza-eSilva e Décio Rocha. 4.ed. São Paulo: Cortez, 2005.

OS DEZ +: uma seleção de livros e eventos culturais indicados pelo caderno. Folha de S. Paulo, São Paulo, 09 mar. 2008a. +Mais!

OS DEZ +: uma seleção de livros e eventos culturais indicados pelo caderno. Folha de S. Paulo, São Paulo, 16 mar. 2008b. +Mais! .

PINTO, M. da COSTA. Sargento Getúlio e Viva o povo brasileiro. Folha de S. Paulo, São Paulo, 08 mar. 2008. Mlustrada.

SANTOS, J. R. dos. Memórias do Cárcere. Folha de S. Paulo, São Paulo, 02 mar. 2008. +Mais!, Biblioteca básica.

TRAVANCAS, I. O livro no jornal: os suplementos literários dos jornais franceses e brasileiros nos anos 90. Cotia: Ateliê, 2001.

VITRINE. Folha de S. Paulo, São Paulo, 08 mar. 2008a. Ilustrada.

VITRINE. Folha de S. Paulo, São Paulo, 29 mar. 2008b. Ilustrada. 


\section{Anexos}

Organizados sob a forma de anexo, dispusemos aqui os textos publicados pela Folha de S. Paulo que foram apresentados no corpo do trabalho, no sentido de procurar demonstrar as recorrências discursivas que privilegiamos em nossa análise.

\section{Anexo 01:}

São Paulo, domingo, 02 de março de 2008 "11

\section{Biblioteca Básica}

\section{Memórias do Cárcere}

\section{JOEL RUFINO DOS SANTOS}

ESPECIAL PARA A FOLHA

Para cada época da vida, tive um livro mais importante: A Bíblia, "Crime e Castigo" (Dostoiévski), "O Ateneu" (Raul Pompéia), "Clara dos Anjos" (Lima Barreto), "Introdução à Revolução Brasileira" (Werneck Sodré). Meu livro de longa duração é "Memórias do Cárcere" [ed. Record], de Graciliano Ramos. Não é ficção, não é memória, não é depoimento político, é tudo isso.

O conteúdo (a brutalidade da cadeia) só se revela por meio daquela forma. "Memórias do Cárcere" é a chave dos romances de Graciliano. A chave está fora, embora também seja texto. Um fora dentro.

JOEL RUFINO DOS SANTOS é professor da Universidade Federal do Rio de Janeiro. Está lançando "Quem Ama Literatura Não Estuda Literatura" (Rocco).

\section{Anexo 02:}

São Paulo, domingo, 09 de março de 2008 thnais.

\section{Biblioteca básica}

\section{Ética contra Estética}

\section{RODOLFO GARCÍA VÁZQUEZ}

ESPECIAL PARA A FOLHA

As relações entre o "belo" e o "bem" vêm me tocando há tempos, e "Ética contra Estética" (ed. Perspectiva), da filósofa espanhola Amelia Valcárcel [foto], se propõe justamente a analisar as relações entre esses conceitos no mundo hoje. Ele o faz a partir das visões dos pensadores clássicos e sem dar uma resposta definitiva a esse combate de valores supremos, que, desde Platão, nunca chegaram a conviver bem. No país de "Tropa de Elite", essa reflexão me parece fundamental para todos os artistas e pessoas de cultura.

RODOLFO GARCÍA VÁZQUEZ é diretor da companhia teatral Os Satyros, que encena "Vestido de Noiva" no Festival de Curitiba, em 23 e 24/3. 
São Paulo, sábado, 08 de março de 2008 Folнa de S.Palio ilustrada

\title{
Livros - Crítica /"Histórias para Ler sem Pressa"
}

Textos irreverentes destacam a sabedoria da tradição árabe

Coletânea apresenta 30 narrativas curtas produzidas entre os séculos 8 e 18 NOEMI JAFFE

\author{
COLABORAÇÃO PARA A FOLHA
}

Conta-se que o padre Antônio Vieira escreveu, numa carta a alguém: "Desculpe, mas não tive tempo de escrever-lhe uma carta mais curta". Algo semelhante acontece na leitura destas "Histórias para Ler sem Pressa", traduzidas da antiga sabedoria árabe por Mamede Mustafá Jarouche.

São 30 histórias, todas muito curtas, para ler com toda a lentidão possível. A sabedoria, mais do que a inteligência, é também uma virtude, próxima de outras como a prudência, a tolerância e a generosidade. E, como elas, desenvolve-se a partir de experiência, intuição, algum senso de espiritualidade e uma visão muito mais generalista do que particular. Tudo isso exige tempo.

De quem pronuncia a sabedoria e de quem a escuta, porque a sabedoria tem a ver com ação, juízo; é a "moral do equilibrista", como diz André Jolles no livro "Formas Simples". E a economia destas histórias é justamente a economia modelar dos sábios, que, com algumas palavras exemplares solucionam revezes e abrem portas labirínticas.

\section{Irreverência}

São 30 histórias extraídas de fontes que vão do século 8 ao século 18, de textos com nomes como "O Livro das Grandes Categorias", "O Livro dos Inteligentes", "O Cúmulo da Sagacidade nas Artes do Decoro" e "O Livro dos Idiotas e dos Néscios".

Nelas comparecem os famosos avarentos, os ridículos ostentadores, o bobo necessário, o esperto que se dá mal no final.

Todos eles desmoralizados por seus opostos, os justiceiros, os generosos, os incorruptíveis, os justos. Tudo com uma simplicidade e polaridade alentadoras para tempos de tantos relativismos, sem, entretanto, cair na austeridade dos juízos morais.

Ao contrário.

Quase todas as histórias do livro são irreverentes, algumas até lembrando personagens brasileiros como o conhecido malandro. E é também surpreendente perceber como os valores da cultura árabe se diferenciam alegremente da moral cristã: nestas histórias, valores como culpa, pecado, punição e vergonha surgem com pesos completamente diferentes daqueles que estamos acostumados a ler nas parábolas do cristianismo.

\section{Verdade na forma}

A verdade, às vezes, parece localizar-se muito mais na linguagem e na forma de dizer as coisas do que em alguma essência última. Assim, quem sabe falar melhor muitas vezes se dá melhor, como na história do "Juiz Austero e do Juiz Ligeiro" ou em "Asnos por Testemunhas". É uma moral muito mais pragmática, afinal de contas.

Trata-se de como e por que agir de determinadas formas, em determinadas circunstâncias da vida cotidiana. E isso parece excluir o "ofereça a outra face" em favor de atitudes de mais 
desconfiança e cautela.

Por exemplo, diante de intrigueiros, são necessárias algumas atitudes como "não acreditar". Advertir o intrigante e torná-lo detestável perante Deus. Afinal, sabedoria é juízo, é siso, mas se dizem que onde tem muito riso, falta o siso, não é o caso deste livro, que, além de fazer pensar, também nos faz rir.

\section{HISTÓRIAS PARA LER SEM PRESSA}

Organização e tradução: Mamede Mustafa Jarouche

Editora: Globo

Quanto: R\$ 25 (80 págs.)

Avaliação: ótimo

\section{Anexo 04:}

São Paulo, sábado, 08 de março de 2008 Folнa de S.Pallo ilustrada

\section{Crítica/"Sargento Getúlio" e "Viva o Povo Brasileiro"}

Ubaldo faz transição do regional ao pós-moderno

"Sargento Getúlio" e "Viva o Povo..." iniciam reedição das obras do baiano

\section{MANUEL DA COSTA PINTO}

\section{COLUNISTA DA FOLHA}

"Sargento Getúlio" e "Viva o Povo Brasileiro" - romances que dão início ao relançamento da obra de João Ubaldo Ribeiro pela Alfaguara/Objetiva- são os dois livros aos quais o escritor baiano deve seu lugar na história da literatura brasileira.

Não se trata de um lugar fixo, congelado nos compêndios de crítica e nos livros escolares. Cada nova edição solicita ao leitor uma releitura e uma reavaliação: seria ele o capítulo final da literatura regionalista ou, ao contrário, um dos primeiros autores a escreverem no Brasil uma prosa pós-moderna, com paródias de outros escritores e estilo camaleônico?

Os livros aqui em questão podem ser interpretados dessas duas maneiras. "Sargento Getúlio", de 1971, narra a história de uma missão política que se transforma em fábula moral.

Getúlio Santos Bezerra é o militar encarregado de levar um prisioneiro do sul da Bahia até o Sergipe.

Durante o trajeto, chegam notícias de que, devido a mudanças na política local, ele deve abandonar a tarefa e libertar o subversivo. Getúlio resolve concluir sua tarefa, desafia as autoridades e torna-se, também ele, um insurgente.

Numa anotação inicial, o autor alerta que a narrativa que virá a seguir "é uma história de aretê" -em referência à palavra grega normalmente traduzida por termos como "virtude", "excelência", "nobreza".

Ou seja, o romance contrasta uma realidade social marcada pelo autoritarismo e pelo concerto dos interesses políticos a uma conduta regida pelo orgulho, por uma noção de virtude menos vinculada à ética cristã (piedosa e privada) do que a uma idéia mediterrânea de honra (viril e pública).

\section{Valores arcaicos}

A obstinação de Getúlio revela apego a valores arcaicos em litígio contra as instituições 
modernas e sua deformação no ambiente agreste. Ocorre que o próprio sargento sofre tal deformação, tratando seu prisioneiro com uma raiva homicida amplificada pela prosa de João Ubaldo -singular mistura de fluxo de consciência e oralidade nordestina.

Ambientado nos anos 50, "Sargento Getúlio" pode ser lido como espelho do Brasil dos anos de chumbo do regime militar; mas esse quadro sócio-político é atravessado por uma idéia de "desmedida" (no sentido da "húbris" grega, que precipitava o conflito nos épicos antigos) que lhe confere caráter atemporal, apesar do enraizamento sertanejo. A viagem simbólica de Getúlio se transforma, em "Viva o Povo Brasileiro" (1984), numa espécie de alegoria na qual são resumidos três séculos de Brasil, desde a ocupação holandesa até o Estado Novo e o golpe de 64, com destaque para as guerras de Canudos e do Paraguai.

\section{Viés satírico}

Com viés mitopóetico e satírico, ambientado no Recôncavo Baiano, o romance segue o trajeto de "alminhas" que migram de geração em geração, encarnando personagens populares que permitem reescrever nossa história a contrapelo e em cronologia descontínua. Esse tipo de recurso, amplamente utilizado pelos escritores do realismo fantástico (como o paraguaio Roa Bastos e o colombiano García Márquez), também levou a comparações com Guimarães Rosa, por seu sentido cosmológico -o que colocaria João Ubaldo como arremate de um ciclo da literatura latino-americana.

O romance, entretanto, faz uma celebração do imaginário afro-baiano (orixás lutando na Guerra do Paraguai, um tom profético que remete aos sermões de padre Vieira) na qual a contestação da história oficial ganha cores eufóricas.

Nesse sentido, o romance indica o caminho tomado por João Ubaldo: se "Sargento Getúlio" identifica na violência e na pulsão de morte uma invariável da história, "Viva o Povo Brasileiro" usa a história para fazer variações de estilo, numa evidente opção pelo entretenimento que será confirmada nos livros seguintes.

\section{SARGENTO GETÚLIO}

Autor: João Ubaldo Ribeiro

Editora: Alfaguara/Objetiva

Quanto: R\$29,90 (168 págs.)

Avaliação: ótimo

\section{VIVA O POVO BRASILEIRO}

Autor: João Ubaldo Ribeiro

Editora: Alfaguara/Objetiva

Quanto: R\$ 64,90 (640 págs.)

Avaliação: bom 


\section{Anexo 05:}

São Paulo, domingo, 09 de março de 2008 thnaํ.

'A morte seria um alívio'

“CARTAS À MÃE” TRAZ O DEPOIMENTO DA POLÍTICA INGRID BETANCOURT, MANTIDA REFÉM PELAS FARC HÁ SEIS ANOS

SYLVIA COLOMBO

\section{DA REPORTAGEM LOCAL}

A cada aniversário de algum de seus filhos, Ingrid Betancourt canta "Happy Birthday" diante de um prato de feijão com arroz, no meio da selva colombiana. No começo, conta, os guerrilheiros permitiam que ela fizesse um bolo de aniversário, mas já não é mais assim. A íntegra da carta que a política franco-colombiana, mantida há seis anos como refém pelas Farc, escreveu em 24 de outubro de 2007, destinada à sua mãe, Yolanda Pulecio, e aos filhos Mélanie e Lorenzo, acaba de ser editada no Brasil.

"Cartas à Mãe - Direto do Inferno" (ed. Agir, 87 págs., R\$ 19,90) reproduz as doze páginas manuscritas por Betancourt, 46.

Juntamente com um vídeo que foi amplamente divulgado pela mídia -no qual Betancourt aparece magérrima e de olhar cabisbaixo-, ambos compõem o retrato de uma mulher desesperançada e em profunda depressão.

Quem acompanhou a libertação feliz, mas controversa, de suas colegas de cativeiro, Clara Rojas e Consuelo Gonzalez, pode perceber como a saúde e o estado psicológico de Betancourt estão fragilizados.

As primeiras exibiam desde a primeira imagem divulgada boa forma física e, de modo geral, nenhum indício de terem sofrido traumas muito graves do ponto de vista mental.

\section{Percepção abalada}

Já Betancourt demonstra, na carta, que sua percepção do mundo está abalada. E que suas forças se esvaem. Conta que anda com dificuldade e lhe custa acompanhar o grupo nas caminhadas pela floresta. Até porque é obrigada a carregar seus poucos pertences quando isso acontece. Enumera seus pertences: um pequeno armário onde guarda uma mochila com roupas e a Bíblia, que chama de "único luxo".

No início, disse que fazia exercícios físicos e até nadava em alguns dos acampamentos. Mas, agora, não sente vontade. Parou de comer, perdeu o apetite, enquanto seus cabelos caem copiosamente. Por fim, admite que sua morte "seria um alívio para todo mundo".

No prefácio do livro, o Nobel da Paz Elie Wiesel diz que os desejos da prisioneira são "simples e perturbadores".

O texto começa com o seguinte cabeçalho: "Selva colombiana, quarta-feira, 24 de outubro, às 8 h34, uma manhã chuvosa, como a minha alma".

\section{Sem política}

A partir daí, Betancourt se dirige à mãe e aos filhos pedindo que eles não deixem de mandar mensagens pelos programas de rádio que chegam à selva.

Pede também que protejam John Frank Pinchao, policial colombiano que foi refém das Farc durante quase nove anos e que conseguiu escapar no ano passado. Era um dos principais companheiros de Betancourt nos últimos tempos. 
Cheia de mensagens pessoais a parentes e amigos, a carta pouco ou nada diz sobre política. Nesse caso, duas explicações são possíveis: ou as Farc não a deixariam passar caso estivesse carregada de mensagens desse naipe ou a ex-candidata à Presidência já não se preocupa mais com esse tema.

Quando menciona líderes internacionais relacionados com seu caso, mesmo díspares ideologicamente, como Chávez, Sarkozy ou Bush, apenas consegue elogiá-los pelos "esforços" em salvar os reféns.

A edição vem acompanhada de um texto-resposta dos filhos Mélanie e Lorenzo DelloyeBetancourt, assim como um posfácio de Francisco Carlos Teixeira da Silva, da Universidade de Brasília.

Seja qual for o desenlace da atual crise na região, as cartas de Betancourt ficarão como um dos mais dramáticos documentos históricos desse episódio.

\section{Anexo 06:}

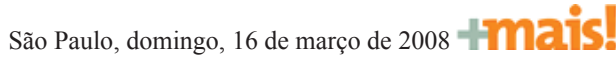

\section{Fé na encruzilhada}

Tolerante, “O Espírito do Ateísmo”, do filósofo André Comte-Sponville, rebate a religião ao invocar o pensamento iluminista

EDUARDO RODRIGUES DA CRUZ

\section{ESPECIAL PARA A FOLHA}

O novo livro de André Comte-Sponville, "O Espírito do Ateísmo", tem como subtítulo "Introdução a uma Espiritualidade sem Deus" e é de fato uma introdução: curto, sem notas de rodapé nem raciocínios tortuosos. É também autobiográfico em estilo: o autor fala a partir de suas próprias experiências e as compara com as tradições filosófica ocidental e oriental. $\mathrm{O}$ autor, como se sabe, faz parte de uma geração de filósofos franceses "pós-68", que, sem ser pós-moderna, transcende o marxismo e o existencialismo de seus mestres. Esses filósofos sentem a necessidade de se colocar a questão de Deus e da religião nos dias de hoje. Eles podem divergir em muitos pontos, mas se consideram proponentes de um humanismo no espírito das luzes e defensores do laicismo.

A presente obra, como nos sugere o título, é uma defesa da dignidade do ateísmo. Ao contrário do biólogo Richard Dawkins e outros "brights" de língua inglesa, entretanto, não faz disso uma cruzada anti-religiosa. É dentro do espírito de tolerância que elabora sua defesa.

Também diferentemente desse segundo grupo, não constrói seu apreço pelo ateísmo em nome da ciência moderna, mas, sim, de valores iluministas: tolerância, liberdade, laicidade. Seu livro se divide em três partes: o primeiro capítulo, intitulado "Pode-se Viver sem Religião?", mostra, assim como muitos de seus contemporâneos, que é possível uma vida plenamente humana e feliz sem professar uma religião ou pertencer a uma igreja. Ao contrário da fé, propõe comunhão (seguindo Durkheim), fidelidade e amor.

O segundo capítulo é mais filosófico e se pauta pela pergunta "Deus existe?". Revisita as tradicionais "provas" da existência de Deus e as refuta seguindo seis argumentos modernos típicos. Mas, novamente, o central é considerar Deus como entrave a um autêntico 
humanismo.

O terceiro capítulo, por fim, expõe sua proposta de uma vida espiritual -"Que Espiritualidade para os Ateus?". Fala aqui de suas experiências e personalidade místicas, reiterando que Deus e a religião barram a realização e a fruição de tais experiências.

Se os dois primeiros capítulos seguem padrões mais ou menos conhecidos, nos quais o autor evita polemizar com os teístas, o terceiro é bastante "sui generis" para o espírito moderno.

\section{"Ateu cristão"}

Michel Onfray qualifica Comte-Sponville como "ateu cristão" (em "Tratado de Ateologia", ed. Martins Fontes) e, com isso, indica uma fraqueza da posição deste, mas nosso autor vê isso como favorável a seu argumento.

Não só ele se coloca em continuidade com a tradição cristã, respeitando-a (por exemplo, ao entender o melhor da religião como "fidelidade" e "respeito ao passado") como também a evoca em defesa de sua espiritualidade. Suas fontes são cristãs e não-cristãs: Lao-tsé e Agostinho, Pascal, Montaigne e Espinosa, Wittgenstein, Krishnamurti e Prajnanpad.

Desses autores, destaca o viés místico e, para melhor caracterizar sua mística, teólogos como De Lubac e Brunner são citados. Esta é estoicista, como ele reitera ao longo do texto. Afirma que sua metafísica (por exemplo, o real como perfeito) e sua postura (por exemplo, serenidade e aceitação) não levam à inação política, mas o argumento não me parece muito convincente.

\section{Consciência crítica}

O autor parece ter sido afetado por uma disposição muito comum na modernidade tardia: uma volta à espiritualidade, mas recusando o Deus cristão e sua igreja.

Busca fontes orientais, mas as traduz em termos de Ocidente, rejeita a metafísica, mas fala com desenvoltura do "absoluto", da "verdade" e de outros universais.

Mas isso pode ser uma vantagem para o leitor que não dispensa uma consciência crítica. É um livro que vale a pena ser lido, não só por apresentar o pensamento de um influente filósofo contemporâneo como por seu estilo agradável, acessível e eminentemente pessoal. Não pude compará-lo com o original francês, mas a tradução não parece apresentar problemas.

EDUARDO RODRIGUES DA CRUZ é professor no departamento de teologia e no programa de pós-graduação em ciências da religião da Pontifícia Universidade Católica (SP).

\section{O ESPÍRITO DO ATEÍSMO}

Autor: André Comte-Sponville

Tradução: Eduardo Brandão

Editora: WMF Martins Fontes (tel. 0/xx/11/ 3241-3677)

Quanto: R\$32,50 (194 págs.) 
São Paulo, domingo, 09 de março de $2008=$ Hก:

Os Dez +

Uma seleção de livros e eventos culturais indicados pelo caderno

+ Literatura

João Ubaldo Ribeiro

Uma caixa traz novamente dois sucessos do escritor, membro da Academia Brasileira de Letras: "Sargento Getúlio" (1971) e "Viva o Povo Brasileiro" (1984), Ganhadores do Jabuti como "autor revelação" e "romance", respectivamente. Objetiva/ Alfaguara (tel. 0/xx/ 21/2199-7824). 168 e 640 págs., R\$ 64.

\section{+ Exposição}

Em Campinas...

... o Ateliê Aberto (tel. 0/xx/ 19/3251-7937) comemora seus dez anos com exposições de Tiago Rivaldo e Reginaldo Pereira. O primeiro apresenta, em vídeo, dois homens transformando suas bicicletas em uma só. Pereira mostra a instalação "Carta Branca", com paisagens marinhas em chave conceitual.

\section{+ Arte}

\section{Countdown}

Em sua primeira exposição individual no Brasil, o artista franco-americano Stephen Dean exibe iconografia pictórica por meio de vídeos, esculturas e pinturas. A Casa Triângulo (tel. 0/xx/11/ 3167-5621), em SP, apresenta sua metodologia artística na série de objetos customizados no térreo.

\section{+ Narrativa}

\section{Kafka à Beira-Mar}

Romance de Haruki Murakami, um dos nomes mais populares da literatura japonesa atual. Fala de um adolescente que foge de casa e de um homem que consegue conversar com gatos. Trad. do japonês de Leiko Gotoda. Ed. Alfaguara/ Objetiva (tel. 0/ xx/ 21/ 21997824). 572 págs., $\mathrm{R} \$ 59,90$.

\section{+ Vídeo}

\section{Cinema de Corredor}

O japonês Koki Tanaka s é o convidado do projeto, com curadoria de Wagner Morales, no centro cultural b-arco (tel. 0/xx/11/3081-6986). Apresenta dez vídeos em que objetos do cotidiano, como lixeiras, caixas de leite, frutas e papel higiênico recebem um olhar terno, sob uma nova perspectiva.

\section{+ Ciência}

\section{Isto É Biologia}

Um dos principais cientistas do século 20, o biólogo Ernst Mayr (1904-2005) traça uma história da disciplina desde os gregos e disserta sobre ética e evolucionismo, defendendo um "humanismo evolutivo". Trad. Claudio Angelo. Companhia das Letras (tel. 0/ xx/11/ 3707-3500). 440 págs., R $\$ 56$. 


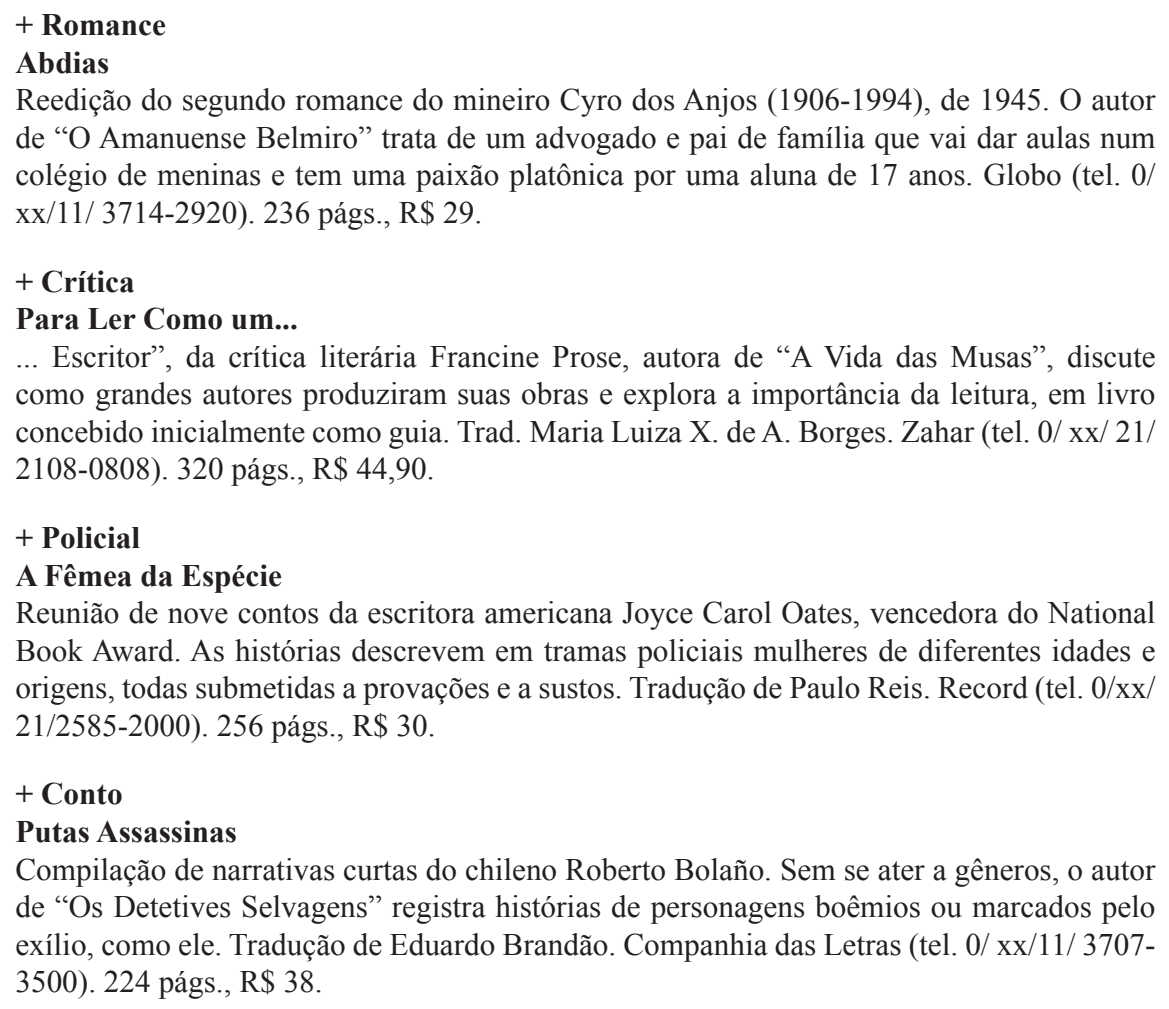
como grandes autores produziram suas obras e explora a importância da leitura, em livro concebido inicialmente como guia. Trad. Maria Luiza X. de A. Borges. Zahar (tel. 0/ xx/ 21/ 2108-0808). 320 págs., $\mathrm{R} \$ 44,90$.

\section{+ Policial}

A Fêmea da Espécie

Reunião de nove contos da escritora americana Joyce Carol Oates, vencedora do National Book Award. As histórias descrevem em tramas policiais mulheres de diferentes idades e origens, todas submetidas a provações e a sustos. Tradução de Paulo Reis. Record (tel. 0/xx/ 21/2585-2000). 256 págs., R\$ 30.

\section{+ Conto}

\section{Putas Assassinas}

Compilação de narrativas curtas do chileno Roberto Bolaño. Sem se ater a gêneros, o autor de "Os Detetives Selvagens" registra histórias de personagens boêmios ou marcados pelo exílio, como ele. Tradução de Eduardo Brandão. Companhia das Letras (tel. 0/ xx/11/37073500). 224 págs., $\mathrm{R} \$ 38$.

\section{Anexo 08:}

São Paulo, domingo, 16 de março de 2008 Hกล:

\section{Os Dez +}

Uma seleção de livros e eventos culturais indicados pelo caderno

\section{+ Pintura}

\section{Oscar Oiwa}

Com 12 pinturas inéditas retratando conflitos geopolíticos de forma irônica, o artista nissei faz sua quarta exposição individual na galeria Thomas Cohn (tel. 0/xx/11/3083-3355), que comemora seus 25 anos. Em abril, ele faz uma retrospectiva de sua obra no Museu de Arte Contemporânea de Tóquio

+ Arte

\section{Pinturas para Peixes...}

... e Outras Pinturas" é a nova série de Rodrigo Andrade, que utiliza óleo sobre tela sobre reprodução do americano Edward Hopper (1882-1967) e nas superfícies internas de aquários, com blocos de tinta em meio a pares de peixes vermelhos e alaranjados. Marília Razuk (tel. 0/xx/11/3079-0853). 


\section{+ Exposição \\ Instabile 2008}

Conhecido por misturar a cultura popular com a erudita, o artista paraense Emmanuel Nassar homenageia Alexander Calder, criando uma versão brasileira dos "Móbiles" e "Estabiles" do escultor norte americano (1898-1976). Na galeria Millan (tel. 0/xx/11/ 3031-6007), em São Paulo.

\section{+ Filosofia}

\section{A República}

A coleção "Livros Que Mudaram o Mundo" traz ensaio do professor de filosofia na Universidade de Cambridge Simon Blackburn sobre a mais importante obra de Platão. Ele aborda o livro no contexto do século 20. Trad. Roberto Franco Valente. Zahar (tel. 0/ xx/21/2108-0808). 188 págs., R\$ 29.

\section{+ Paleontologia}

O Povo de Luzia...

... - Em Busca dos Primeiros Americanos" traz o relato dos pesquisadores Walter Neves e Luís Piló sobre descobertas como a do fóssil de mais de 10 mil anos encontrado em Lagoa Santa (MG), suscitando discussões sobre os modos de vida de nossos ancestrais. Ed. Globo (tel. 0/xx/ 11/ 3714-2920).

\section{+ Coletânea}

O Mito Individual...

... do Neurótico" reúne três textos de Jacques Lacan. O psicanalista aborda a função religiosa do símbolo e discute, a partir das idéias de Lévi-Strauss, a relação dos mitos com a estrutura das sociedades primitivas. Trad. Claudia Berliner. Zahar (tel. 0/ xx/21/ 2108-0808). 104 págs., $\mathrm{R} \$ 29$.

\section{+ Romance}

\section{A Mulher que Fugiu...}

... de Sodoma", primeiro romance de José Geraldo Vieira (1897-1977), de 1931, ganha reedição. Elogiado por autores como Manuel Bandeira e Erico Verissimo, Vieira cria uma ficção urbana e carioca utilizando o jogo como pano de fundo. Ed. Leitura (tel. 0/xx/ 31/ 3379-0620). 420 págs., $\mathrm{R} \$ 45$.

\section{+ História}

\section{Ascensão e Queda...}

... do Terceiro Reich", clássico do jornalista americano William L. Shirer (1904-1993), apresenta os eventos da Segunda Guerra por quem acompanhou o conflito de perto. Tradução de Pedro Pomar e Leônidas Gontijo de Carvalho. Agir (tel. 0/xx/21/3882-8200). 880 págs. (vol. 1) e 768 págs. (vol. 2), R\$ 89,90 cada.

\section{+ Importado}

Nothing to Be...

... Frightened of", último livro de Julian Barnes, autor de "O Papagaio de Flaubert", acaba de sair no Reino Unido. O romance (Nada para Temer, ed. Jonathan Cape, 256 págs., 16,99 libras, R\$ 58) é um misto de memórias familiares, ensaio sobre a morte e reflexões acerca da obra do escritor francês Jules Renard. 


\section{+ Policial \\ Vestígio}

Patricia Cornwell, uma das principais autoras de romances policiais dos EUA, retoma sua personagem Kay Scarpetta. A médica legista tenta esclarecer agora o assassinato de uma garota de 14 anos. Trad. Otacílio Nunes e Claudio Carina. Cia das Letras (tel. 0/ xx/11/ 3707-3500). 448 págs., $\mathrm{R} \$ 49$.

\section{Anexo 09:}

São Paulo, sábado, 08 de março de 2008 FOLна de S.PAwo ilustrada.

Vitrine

FICÇÃO

\section{Contos/Ficção Científica A Cidade Inteira Dorme \\ RAY BRADBURY}

Editora: Globo; Tradução: Deisa Chamahum Chaves; Quanto: R\$27 (196 págs.)

SOBRE O AUTOR: Nascido em 1920, em Waukegan, Illinois, o escritor norte-americano é um dos principais nomes da ficção científica. Publicou "As Crônicas Marcianas", "Algo Sinistro Vem Por Aí", "Uma Estranha Família -Lembranças de um Lugar do Passado" e "Fahrenheit 451" (adaptado para o cinema por François Truffaut), entre outras obras. Roteirista, assinou o texto de filmes como "Moby Dick" (1956), de John Huston.

TEMA: Reunião de contos do renomado autor, incluindo alguns que já tornaram-se célebres, como "O Pedestre", "O Lixeiro" e "O Homem Ilustrado".

POR QUE LER: A coletânea de narrativas curtas de Bradbury revela a grande habilidade literária do autor, que passeia pelo terror psicológico, pelo fantástico e pela crítica política.

\section{Romance \\ La Bodega \\ NOAH GORDON}

Editora: Rocco; Tradução: Pinheiro de Lemos; Quanto: R\$ 39,50 (328 págs.)

SOBRE O AUTOR: Nascido em 1926, o escritor norte-americano tem entre seus bestsellers os livros "O Físico", "O Rabino", "Xamã" e "O Último Judeu".

TEMA: Na França, no fim do século 19, depois de ir à guerra, jovem descobre a arte da produção do vinho. Após a morte do pai, volta à Espanha natal. onde enfrenta problemas financeiros e conflitos familiares.

POR QUE LER: Lançado primeiro na Espanha, com tiragem inicial de 200 mil exemplares, livro está nas principais listas de mais vendidos do país. O autor estava afastado da ficção há oito anos.

\section{NÃO-FICÇÃO}

\section{História}

Creta

\section{ANTONY BEEVOR}

Editora: Record; Tradução: Maria Beatriz de Medina; Quanto: R\$ 55 (462 págs.)

SOBRE O AUTOR: Educado em Winchester e na Academia Militar de Sandhurst, deixou o Exército após cinco anos para se dedicar à literatura e já publicou livros de ficção e nãoficção, entre eles "Stalingrado" e "O Mistério de Olga Tchekova". 
TEMA: A história da rendição da Grécia, na Batalha de Creta, e da resistência cretense à invasão nazista, durante a Segunda Guerra Mundial.

POR QUE LER: Obra traz relatos de participantes-chave do confronto e recebeu críticas positivas de jornais como "The Independent" e "The Daily Telegraph", entre outros.

\section{Medicina/Administração \\ Por que as Zebras Não Têm Úlceras? \\ ROBERT M. SAPOLSKY}

Editora: Francis; Tradução: Ana Carolina Mesquita; Quanto: R\$ 89 (592 págs.)

SOBRE O AUTOR: Biólogo e neurologista, professor da Universidade Stanford, nos EUA, é também autor de "Memórias de um Primata".

TEMA: Resultado de pesquisa de mais de 20 anos, livro se debruça sobre os problemas ligados ao estresse, da insônia às doenças cardíacas.

POR QUE LER: Com ilustrações e mais de cem páginas de notas, obra é um sério estudo científico e, no entanto, não perde o viés bem-humorado.

\section{Anexo 10:}

São Paulo, sábado, 29 de março de 2008 folHa des.Pacioilustrada

Vitrine

FICÇÃO

\section{Romance}

Partículas Elementares

MICHEL HOUELLEBECQ

Editora: Sulina; Tradução: Juremir Machado da Silva; Quanto: R\$ 45 (296 págs.)

SOBRE O AUTOR: Nasceu em 1958 na ilha Reunião, no oceano Índico. Viveu em Argel (Argélia), indo em 1961 para Paris. Começou carreira com poesia, passou para os romances e hoje também se dedica ao cinema. Do escritor, saíram no Brasil os livros "Extensão do Domínio da Luta" (Sulina) e "Plataforma" e "A Possibilidade de uma Ilha" (Record).

TEMA: O biólogo Michel sublima o declínio da sua sexualidade no trabalho, nas compras e no uso de tranqüilizantes. Já seu meio-irmão, Bruno, vive uma busca desesperada do prazer sexual.

POR QUE LER: Lançado originalmente em 1998 e publicado em mais de 30 países, o romance polêmico consagrou Houllebecq em todo o mundo. A reedição vem por ocasião do lançamento da versão para o cinema do diretor alemão Oskar Roehler.

\section{Poesia}

Toda Poesia de Machado de Assis

\section{MACHADO DE ASSIS}

Editora: Record; Quanto: R\$ 85 (756 págs.)

SOBRE O AUTOR: Considerado um dos maiores escritores brasileiros, Machado de Assis (1839-1908) foi cronista, contista, poeta, novelista, romancista, crítico e ensaísta. Escreveu "Memórias Póstumas de Brás Cubas" e "Dom Casmurro", entre outros.

TEMA: Cerca de 180 poemas de Machado de Assis, do primeiro soneto, "À Ilma. Sra. D.P.J.A.” (1854), ao último, “A Carolina” (1906). Organização de Cláudio Murilo Leal. 
POR QUE LER: A antologia faz parte das comemorações dos cem anos de morte do autor, cuja obra poética é reunida pela primeira vez aqui em um só volume.

\section{NÃO-FICÇÃO}

\section{Ciência}

Descobertas Perdidas

DICK TERESI

Editora: Companhia das Letras; Tradução: Rosaura Eichenberg; Quanto: R\$ 59 (440 págs.)

SOBRE O AUTOR: Escritor norte-americano, lançou obras como "The Dog Particle", entre outras. Colabora para as revistas "Discover" e "The New York Times Magazine".

TEMA: Decisivas descobertas da história da ciência que foram desenvolvidas por maias, árabes e gregos, entre outros, mas que foram minimizadas pela leitura eurocêntrica.

POR QUE LER: A apresentação das “descobertas perdidas" feita por Teresi tem variados exemplos, escritos de forma bastante clara.

\section{História}

\section{Japoneses - A História do Sol Nascente \\ MARCIA YUMI TAKEUCHI}

Editora: Lazuli/Companhia Editora Nacional; Quanto: R\$ 18 (152 págs.)

SOBRE A AUTORA: Historiadora com doutorado na USP (Universidade de São Paulo), é pesquisadora do Proin (Projeto Integrado Arquivo/ Universidade) e do Leer (Laboratório de Estudos sobre Etnicidade, Racismo e Discriminação).

TEMA: Edição de bolso que traz a história da imigração dos japoneses para o Brasil, que neste ano completa o centenário.

POR QUE LER: A série "Imigrantes no Brasil" da Lazuli, coordenada pela professora Maria Luiz Tucci Carneiro, traz assuntos históricos com uma abordagem clara, mas não superficial.

\section{Anexo 11:}

São Paulo, domingo, 02 de março de $2008=$ Hก:

+ Lançamentos

\section{Brasil - Paisagens Naturais}

128 págs., R\$ 25,90 de Marcelo Leite. Ática (av. Otaviano Alves de Lima, 4.400, CEP 02909-900, SP, tel. 0/xx/11/3990-1777). Doutor em ciências sociais pela Unicamp, o colunista da Folha apresenta os seis biomas do Brasil, em livro ilustrado por diversas fotos. O prefácio é da ministra do Meio Ambiente, Marina Silva.

\section{As Obras do Amor}

432 págs., R\$ 66,70 de Soren A. Kierkegaard. Vozes (r. Frei Luís, 100, CEP 25689-900, Petrópolis, RJ. tel. 0/xx/24/2231-4676). O teólogo e filósofo dinamarquês (1813-1855) analisa, nestas considerações de 1847, o mandamento do amor cristão comparado ao amor platônico e à amizade aristotélica. 


\section{Hibridismos Musicais de Chico Science e Nação Zumbi}

248 págs., R\$ 33 de Herom Vargas. Ateliê Editorial (estrada da Aldeia de Carapicuíba, 897, CEP 06709-300, Cotia, SP, tel./fax 0/ xx/11/4612-9666). Pesquisador de música, cultura e linguagens da mídia do CNPq, Vargas analisa a combinação de tradição e cosmopolitismo nos dois discos gravados antes da morte de Chico Science, em 1997.

\section{Para Além dos Direitos}

384 págs., R\$ 46 de Haroldo Abreu. Editora UFRJ (av. Pasteur, 250, sala 107, CEP 22290902, RJ, tel. 0/xx/21/2542-7646). Professor da Universidade Federal Fluminense, Abreu busca reconstituir o conceito de "cidadania" como modo de pertencer ao ordenamento social, dentro da divisão capitalista do trabalho.

\section{Os Bastidores do Second Life}

288 págs., R\$ 39,90 de Wagner James Au. Tradução de Fal Vitiello de Azevedo. Idéia \& Ação (r. Cristiano Viana, 1216, CEP 05411-002, SP, tel. 0/xx/11 3873-2062). O jornalista narra a evolução do site Second Life, aborda engenharia social, identidade, romances, código de ética e discute como organizações podem utilizar o ambiente virtual. Inclui glossário.

\section{Homenagem - 80 Anos de Evanildo Bechara}

200 págs., R\$29,90 Dieli Vesaro Palma, Maria Mercedes Saraiva Hackerott, Neusa Barbosa Bastos e Rosemeire Leão Silva Faccina (orgs.). Nova Fronteira (r. Bambina, 25, CEP 22251-050, RJ, tel. 0/ xx/21/ 2131-1111). Coletânea de ensaios que abordam o trabalho do gramático e lingüista Evanildo Bechara, membro da Academia Brasileira de Letras. Os textos discutem normas e prescrição lingüística, entre outros temas.

\section{Racismo e Discurso na América Latina}

384 págs., R\$ 37 Teun A. van Dijk (org.). Contexto (r. Doutor José Elias, 520, CEP 05083030, SP, tel. 0/xx/11/3832-5838. Traz ensaios de diversos autores analisando o que definem como formas de racismo embutidas nas sociedades de países latino-americanos como Brasil, Argentina, Chile, Colômbia e Guatemala.

\section{Um Sete Um}

112 págs., R\$ 27 de Ítalo Ogliari. 7 Letras (r. Jardim Botânico, 600, sala 307, CEP 22461000, RJ, tel. 0/xx/21/2540-0076). Em seu primeiro romance, o autor, mestre em literatura pela Pontifícia Universidade Católica - RS, narra a história de um homem que resolve contar sua vida a um mendigo, a quem trata como se fosse seu pai.

\section{O Poeta e a Consciência Crítica}

216 págs., R\$ 35 de Affonso Ávila. Perspectiva (av. Brigadeiro Luís Antônio, 3.025, CEP 01401-000, SP, tel. 0/xx/11/3885-8388). Nesta coletânea de ensaios originalmente lançada em 1969, as tensões entre consciência crítica e liberdade criativa, tradição e vanguarda na literatura brasileira são analisadas pelo poeta e crítico literário mineiro.

\section{Leitura, Literatura Infanto-Juvenil e Educação}

314 págs., R\$ 45 de Célia Regina Delácio Fernandes. Editora da Universidade Estadual de Londrina (campus universitário, s/nº, CEP 86051-990, Londrina, PR, tel. 0/ xx/ 43/3371- 
4673). Professora e pesquisadora da Universidade Federal da Grande Dourados, a autora aborda o papel da escola como mediadora na divulgação de livros voltados para o segmento infanto-juvenil.

\section{Anexo 12:}

São Paulo, domingo, 30 de março de 2008 thàis.

+ Lançamentos

\section{A Saúde Pública no Rio de Dom João}

120 págs., R\$ 29,90 de Manoel Vieira da Silva e Domingos R. dos Guimarães Peixoto. Senac Rio (av. Franklin Roosevelt, 126/604, CEP 20021-120, RJ, tel. 0/xx/21/2510-7100). No primeiro destes dois textos de época, Silva destaca a influência do clima quente e úmido sobre o solo e sugere o aterramento das áreas pantanosas, que poderiam ser foco de doenças. No outro, Peixoto aponta a importância da chegada da família real para o avanço na saúde pública.

\section{A Memória, a História, o Esquecimento}

536 págs., R\$ 82 de Paul Ricoeur. Trad. Alain François. Ed. Unicamp (r. Caio Graco Prado, 50, Cidade Universitária, CEP 13083-892, Campinas, SP, tel. 0/xx/ 19/3788-7235). O filósofo francês (1913-2005) resume seus estudos sobre a memória em três partes. Na primeira, enfoca os fenômenos mnemônicos; na segunda, a epistemologia das ciências históricas; na terceira, conclui com uma análise hermenêutica da condição histórica dos seres humanos.

\section{Música em Debate}

256 págs., R\$ 39 Samuel Araújo, Gaspar Paz e Vicenzo Canbria (orgs.). Faperj/Mauad (r. Joaquim Silva, 98, $5^{\circ}$ andar, CEP 20241-110, RJ, tel. 0/xx/21/3479-7422). Nove ensaios, escritos por nomes como Flávia Camargo Toni e Henrique Gandelman, que enfocam temas como acervos fonográficos de música em tradição oral, direito autoral e as diversas formas de propriedade intelectual e as inter-relações musicais entre África e América.

\section{Sartre e o Pensamento Mítico}

248 págs., R\$ 30 de Caio Liudvik. Ed. Loyola (r. 1.822, n 347, CEP 04216-000, São Paulo, SP, tel. 0/ xx/11/6914-1922). Mestre em filosofia pela USP, o autor analisa a estréia de Sartre (1905-80) como dramaturgo, em 1943, com “As Moscas" -em que recria a tragédia grega “Orestéia” (Ésquilo) sob a ótica da ocupação nazista da França.

\section{Hegel e o Estado}

656 págs., R\$ 118 de Franz Rosenzweig. Tradução de Ricardo Timm de Souza. Perspectiva (av. Brigadeiro Luís Antônio, 3.025, SP, CEP 01401-000 tel. 0/xx/11/ 3885-8388). Considerada obra de grande importância nas pesquisas sobre a filosofia de Friedrich Hegel (1770-1831), traz o conceito de Estado em sua obra. Prefácio do filósofo Roberto Romano. 


\section{Escrever sobre Escrever}

216 págs., R\$ 33 de Claudia Amigo Pino e Roberto Zular. WMF Martins Fontes (r. Conselheiro Ramalho, 330, CEP 01325-000, SP, tel. 0/xx/11/3241-3677). Os autores descrevem as ferramentas próprias ao método da crítica genética -ou crítica do processo, dedicada ao estudo dos manuscritos- desde seu surgimento, na efervescência de 1968, em Paris.

\section{Ritual, Risco e Arte Circense}

316 págs., R\$ 40 de Guilherme Veiga. Universidade de Brasília (SCS, quadra 2, bloco C, $\mathrm{n}^{\mathrm{o}}$ 78, ed. OK, $1^{\circ}$ andar, CEP 70302-907, Brasília, DF, tel. 0/xx/61/3035-4211). Tese de doutorado em sociologia que aborda a performance e as fronteiras epistemológicas e conceituais entre a arte e o circo, além de traçar o panorama do desenvolvimento do espetáculo circense.

\section{Revoluções de Independências e Nacionalismos nas Américas}

244 págs., R\$ 30 Marco A. Pamplona e Maria Elisa Mäder (orgs.). Tradução de Miriam Xavier e Patrícia Zimbres. Ed. Paz e Terra (r. do Triunfo, 177, CEP 01212-010, São Paulo, SP, tel. 0/xx/ 11/3337-8399). Ensaios discutem a Independência mexicana, o papel tradicional da mulher e a xenofobia nos discursos político e religioso.

\section{Sotaques d'Aquém e d'Além Mar}

240 págs., $\mathrm{R} \$ 44,90$ de Manuel Carlos Chaparro. Summus (r. Itapicuru, 613, $7^{\circ}$ andar, CEP 05006-000, SP, tel. 0/xx/11/3872-3322). O doutor em comunicação e professor de jornalismo na Universidade de São Paulo compara as classes de texto jornalístico de Brasil e de Portugal e propõe uma teoria dos gêneros.

\section{Anexo 13:}

São Paulo, domingo, 02 de março de 2008 Folha de S.PAtuoilustrada

\section{Coleção traz Drummond dos temas sociais}

“O Sentimento do Mundo", do escritor mineiro, é o quarto volume da série

Livro de 1940 que chega às bancas no próximo domingo revela acirramento de questões políticas do poeta

DA REPORTAGEM LOCAL

Surgido na arena literária em 1930 com o lançamento da coletânea "Alguma Poesia", Carlos Drummond de Andrade (1902-1987) rapidamente firmou-se como um dos principais poetas brasileiros.

Na verdade, em seu território específico -no qual se evidenciam a ironia e o distanciamento, a dialética entre o pessoal e o social, uma antilírica assentada no raciocínio lógico-, Drummond reina de modo absoluto em nossas letras.

"Sentimento do Mundo" (1940) -quarto volume da "Coleção Folha Grandes Escritores Brasileiros", que chega às bancas no próximo domingo- representa um acirramento das preocupações sociais do poeta, cujo auge se dá em "A Rosa do Povo" (1945), até hoje seu 
livro mais político.

O tema social não surge isolado, mas se vincula a um "eu" que se vê acaçapado por um mundo que não compreende e mal consegue suportar. Devemos lembrar que, no Brasil, vivia-se sob a ditadura do Estado Novo e, no cenário mundial, eclodia então a Segunda Guerra Mundial.

Assim, o sentimento que o poeta tem do mundo é de algo descomedido e doloroso. "Esse amanhecer/ mais noite que a noite", começa. Adiante, confessa-se pequeno: "Não, meu coração não é maior do que o mundo. É muito menor".

Embora observe que o mundo "não pesa mais que a mão de uma criança", não acredita que um ser humano apenas, em seu arrepio existencial, possa fazer a diferença: "porque não podes, sozinho, dinamitar a ilha de Manhattan".

Se em "O Sentimento do Mundo" a ação ainda não parece possível, existe a esperança na atividade poética, aquela que aproxima o poeta de sua gente e de seu tempo: "Não serei o poeta de um mundo caduco./ Também não cantarei o mundo futuro. [...] O tempo é a minha matéria, o tempo presente, os homens presentes,/ a vida presente".

\section{Anexo 14:}

São Paulo, domingo, 30 de março de 2008 Fol.ha DES.PAtu ilustrada

\section{Livro de Lima Barreto é o próximo da "Coleção"}

\section{"Triste Fim..." estará à venda nas bancas no dia 6/4}

\section{DA REPORTAGEM LOCAL}

Um major, subsecretário do Arsenal de Guerra, patriota exaltado que insiste para que o tupi-guarani seja decretado "língua oficial e nacional do povo brasileiro", é o protagonista de "Triste Fim de Policarpo Quaresma", o oitavo volume da série "Coleção Folha Grandes Escritores Brasileiros".

Trata-se do principal romance de Lima Barreto (1881 -1922), escritor que nasceu pobre, viveu como pequeno funcionário e publicou artigos e romance em jornais, inclusive "Triste Fim..." (lançado em folhetins, no "Jornal do Comércio", em 1911).

Nem o autor obteve sucesso, nem sua voz teve o crédito merecido na conservadora sociedade do início do século 20.

Dado a crises de depressão, alcoólatra, Barreto internou-se duas vezes no Hospício Nacional. Morreu de colapso cardíaco, com apenas 41 anos.

Durante algum tempo a crítica se pautou em localizar indícios autobiográficos em sua ficção, que também era acusada de não exibir bastante sofisticação artística. Mas a verdade é que, como um todo, sua obra transcende essa conjuntura redutora.

Policarpo é mais do que Barreto. O personagem representa o nacionalista íntegro e ingênuo, que não compreende as engrenagens que movem os interesses políticos e acabam por esmagá-lo.

Nesse sentido, Policarpo não deixa de ser um sonhador nos moldes de Dom Quixote.

Como observou o crítico Oliveira Sobrinho: "Ambos são otimistas incuráveis, porque acreditam que os males sociais e sofrimentos humanos podem ser curados pela mais simples e ao mesmo tempo mais difícil das terapêuticas, que é a aplicação da justiça da qual um e outro se arvoraram paladinos".

Se há muito de sátira nos traços e no comportamento de Quaresma, e esta convida ao riso, trata-se de um riso amargo, pois esbarra no estado melancólico que envolve o personagem, 
cujo destino parece ser o de todos os que crêem em um ideal caduco ou impossível.

Ao sair do hospício, Quaresma se envolve na Revolta da Armada (1893) na condição de defensor do presidente Floriano Peixoto, que chega a lhe dizer: "Você, Quaresma, é um visionário...".

Mas o presidente se revela um ditador, e seu admirador, sem que este último saiba bem por quê, acaba preso e condenado como traidor.

As palavras com que, em carta à irmã, ele exprime seu desalento são de um patetismo poucas vezes alcançado na ficção brasileira. Lembram o monólogo final de Macbeth, antes da queda de seu reino: "Esta vida é absurda e ilógica [...] Ninguém compreende o que quero, ninguém deseja penetrar e sentir; passo por doido, tolo, maníaco e a vida se vai fazendo inexoravelmente com a sua brutalidade e fealdade."

O livro “Triste Fim de Policarpo Quaresma" estará à venda nas bancas no próximo domingo.

Recebido em fevereiro de 2013.

Aprovado em maio de 2013. 
